\title{
O TEXTO COMO TECIDO NARRATIVO E O IMAGINÁRIO DAS ROUPAS NA OBRA DE ANAÏS NIN
}

\section{TEXT AS A NARRATIVE TISSUE AND THE IMAGINARY OF CLOTHES IN ANAÏS NIN'S WORK}

\author{
Cinara Ferreira ${ }^{1}$, Camila Nascimento Cardozo ${ }^{2}$ \\ "Não consigo deixar de sentir hoje que uma parte de mim \\ fica de lado me observando viver e maravilhando-se." \\ Anaïs Nin, Henry \& June.
}

\begin{abstract}
The literary text, according to Roland Barthes (2010), is like a tissue, in which several elements of the narrative make a web that entails both the writer and the reader. The descriptive details present in the narrative tissue, also produce significance, although seemingly insignificant. (BARTHES, 1972). Based on these assumptions, in a Barthesian approach, this paper proposes a search for the meanings of descriptive details in Anaïs Nin's narratives and the relationship between literature, fashion and the imaginary. The main elements of this paper are fragments referring to characters' costumes in some Nin's short stories, as well as in the novel Henry \& June (2014). I analyze how these elements help composing the characters and the narratives' contexts, going through the relationship between clothes, fabrics and eroticism, historical context and personalities, considering texts are themselves like tissues, as Barthes proposes.
\end{abstract}

KEYWORDS: fashion; narrative; tissue.

RESUMO: O texto literário, para Roland Barthes (2010), é como um tecido, no qual vários elementos da narrativa compõem uma trama que enreda tanto o escritor quanto o leitor. Os detalhes descritivos presentes no tecido narrativo também produzem significação, embora aparentemente tenham menor importância. (BARTHES, 1972). Partindo destes pressupostos, em uma abordagem barthesiana, este trabalho propõe uma busca por significados nos detalhes descritivos em narrativas de Anaïs Nin e a relação entre literatura, moda e imaginário. Os elementos que constituem a pedra de toque deste trabalho são fragmentos de alguns contos de Anaïs Nin, referentes aos trajes das personagens, bem como do romance Henry \& June (2014). Analiso como estes elementos contribuem na caracterização das personagens e contextualização das narrativas, passando pela relação entre roupas, tecidos e erotismo, contexto histórico e traços de personalidade, considerando os próprios textos como tecidos, como propõe Barthes.

KEY-WORDS: moda; narrativa; tecido.

\footnotetext{
${ }^{1}$ Professora Doutora do Instituto de Letras da Universidade Federal do Rio Grande do Sul.

${ }^{2}$ Mestranda do Programa de Pós-Graduação em Letras da Universidade Federal do Rio Grande do Sul.
} 


\section{A descrição no tecido textual}

Em “O Efeito de Real” (1972), Roland Barthes constata que a análise feita pelos estruturalistas até aquele momento pouco se atenta aos detalhes descritivos do texto narrativo. Como se estes detalhes não tivessem importância ou significado no desenrolar da história, como se enxertassem espaços entre elementos mais relevantes para a análise estrutural. Este desinteresse pela descrição é questionado por Barthes:

A singularidade da descrição (ou do "detalhe inútil") no tecido narrativo, sua solidão, aponta para uma questão que tem a maior importância para a análise estrutural dos discursos narrativos. Esta questão é a seguinte: tudo, no discurso narrativo, é significante, e se não for, se subsistem no sintagma narrativo algumas regiões insignificantes, qual é definitivamente, se assim podemos dizer, a significação dessa insignificância? (BARTHES, 1972, p.37).

Quando lemos um texto narrativo de outra época, buscamos os detalhes que habitam o imaginário de um tempo longínquo em algumas referências visuais, como os filmes e programas de televisão de época aos quais já assistimos, ou as fotos que nossos avós nos mostravam, em sépia ou preto e branco, no álbum de família. Quantos de nós já não passamos pela situação de imaginar um cenário com objetos particulares ao ouvir um adulto da família contando acontecimentos anteriores à nossa existência? Esse processo de criação, se poderíamos chamar assim o funcionamento da imaginação, acontece de acordo com as referências que temos à disposição, em relação ao que pertencia àquele tempo, cuja narrativa geralmente começa com: “Antigamente, quando você não havia nascido...”. Mesmo na idade adulta, muitos de nós, que apreciamos a ficção, e também a História, cultivamos um fascínio por antiguidades, como a vitrola, os discos, os prédios históricos, os carros antigos. Costumamos associar a beleza material encontrada nestas raridades a algumas histórias imaginárias. O contrário também ocorre: uma história se torna mais interessante se pudermos projetar mentalmente cenário, figurino, gestos, um outro mundo à parte de nossa realidade cotidiana.

Mesmo não se tratando de uma narrativa, mas de uma reflexão teórica sobre a literatura e a semiologia, a própria linguagem de Barthes em sua crítica é abundante em elementos visuais, que aproximam as ideias que o autor deseja transmitir de nosso mundo físico. Deste modo, é possível imaginar o que lemos em um movimento de aproximação à realidade acessível dos elementos concretos que ali funcionam como figuras de linguagem. Um exemplo é o uso da palavra "tecido". Barthes refere-se ao "tecido narrativo" e ao "tecido 
descritivo" como componentes de um texto. É fácil imaginar a confecção de um texto, composto de fios delicados que se envolvem em uma trama resistente, até que toma nova forma e dimensão. O escritor tece aos poucos e, ao final do trabalho, só pode cortar do texto o que sobrar, na fase de acabamento. Se alguns detalhes supostamente insignificantes permanecem no texto após esse acabamento, ao contrário do que pode parecer em uma leitura superficial, há significação neles. Se a descrição forma um tecido, assim como a narração, ela tem importância, mesmo que, segundo Barthes, alguns estruturalistas ignorem sua existência.

A ideia de texto como tecido se faz mais presente em O Prazer do Texto (BARTHES, 2010), onde o teórico lança um olhar para a experiência do leitor, que ultrapassa a intenção do escritor e até mesmo a forma do texto.

Texto quer dizer Tecido; mas, enquanto até aqui esse tecido foi sempre tomado por um produto, por um véu todo acabado, por trás do qual se mantém, mais ou menos oculto, o sentido (a verdade), nós acentuamos agora, no tecido, a ideia gerativa de que o texto se faz, se trabalha através de um entrelaçamento perpétuo; perdido neste tecido - nessa textura - o sujeito se desfaz nele, qual uma aranha que se dissolve ela mesma nas secreções construtivas de sua teia. Se gostássemos dos neologismos, poderíamos definir a teoria do texto como uma hifologia (hyphos é o tecido e a teia da aranha). (BARTHES, 2010, p.74).

Em “O Efeito de Real”, Barthes se dedica a uma rica explicação sobre a influência da descrição desde a Antiguidade, para fins estéticos, na retórica clássica até a neo-retórica Alexandrina, então salta para o período realista em que Flaubert utiliza o tecido descritivo. No caso de Flaubert, a descrição tem uma função diferente daquela utilizada tanto na Antiguidade quando na Idade Média. Ela não só tem uma finalidade estética, de tornar belo, como também intenta, mesmo não sendo o próprio real, imprimir um efeito de aproximação do real na leitura, tendo um sentido de ser apresentada. Para Barthes, em Flaubert "toda a descrição é construída visando aparentar Rouen a uma pintura: é uma cena pintada de que a linguagem se encarrega (Assim, vista do alto, toda a paisagem tinha o ar imóvel como uma pintura)". (BARTHES, 1972, p.39).

O efeito da descrição da cidade de Rouen em Madame Bovary se assemelha ao das descrições na obra de Anaïs Nin, em nossas experiências de leitura. Em muitas das narrativas escritas por Anaïs Nin, a autora se dedica a numerosas descrições detalhadas dos cenários, das formas físicas das personagens, dos figurinos, dos gestos. Alguns destes elementos são descritos objetivamente, em formas, cores, tamanhos e proporções, outros subjetivamente, no impacto sensorial e emocional que provocam no narrador ou nas personagens. Existe um jogo 
entre o narrador e o leitor, em que se oferece uma parte da descrição (física ou de impressões subjetivas e abstratas), pronta a se complementar pela imaginação pelo que não está dito.

Por exemplo, a escolha de um tecido pode não trazer um significado exato, e para alguns leitores pode ser que não tenha importância, mas para outro que se proponha a adaptar a narrativa para outra linguagem, pode ser importante na montagem. Para um sinesteta, as palavras lidas se originam nas ideias e atingem o corpo no mesmo instante. As experiências de leitura dos sinestetas são tão subjetivas que descrevê-las é um risco. "As confissões de um sinesteta devem parecer tediosas e pretensiosas àqueles que são protegidos de tais vazamentos e correntes de ar por paredes mais sólidas que as minhas." (NABOKOV, 2014, p.35). Para estudiosos de teorias do imaginário e da semiologia, estes detalhes jamais devem passar despercebidos, eles podem fornecer muito mais informações do que aquilo que está dito e evidente em uma narrativa. Estes detalhes completam lacunas ou provocam questionamentos inevidentes, como quando o cientista lança um olhar para uma pequena mostra do material pesquisado através do microscópio.

\section{Descrição das roupas em Anaïs Nin}

Tomando como exemplo o conto "A Model” (NIN, 1979) há uma passagem em que a narradora-personagem, uma modelo em início de carreira, almoça com as colegas e tenta uma conversa, sem muito sucesso, quando contempla a cena seguinte cena: "One girl had lifted up her skirt and was examining a mole way up her thighs. I saw that she was not wearing panties, just a black satin dress which clung to her." (NIN, 1979, p.68). Para um leitor que não se atenha muito a descrições, esta passagem pode parecer sem muita importância, pois a cena apresentada não tem uma sequência, e a personagem observada pela narradora não reaparece. Para alguém que, como nós, dê mais importância às imagens, o gesto e as vestes da moça podem se destacar na narrativa, despertando mais curiosidade que os diálogos subsequentes com outros personagens. Roland Barthes, em "Língua e Fala, Indumentária e Traje” (2005), compara a linguagem das roupas à linguagem verbal, em que se atribui sentido às roupas.

A impressão causada por um vestido de cetim é diferente daquela que teríamos se o vestido fosse, por exemplo, de veludo. Esta diferença de texturas provoca emoções diferentes. 
Podemos imaginar o frescor do cetim, no imediato ato de vestir, e o calor absorvido pelo tecido ao longo do tempo; poderíamos imaginar o calor do veludo no contato imediato com a peça. Imaginar este ou aquele tecido pode trazer conforto, prazer ou incômodo, conforme as memórias pessoais de cada leitor do contato com estes tecidos, das temperaturas, texturas, caimentos e reflexo da luz, e também de acordo com o imaginário coletivo dos tecidos. $\mathrm{O}$ material escolhido determina o efeito. Anaïs Nin escolhe a leveza e sensualidade do cetim, que evidencia melhor as formas do corpo. É importante lembrar que o cetim, tecido sintético de alta luminosidade e espessura fina, além de aparecer em vestes para ocasiões como festas e passeios, também é comumente utilizado na confecção de moda íntima há séculos ${ }^{3}$, como base para anáguas, camisolas, chambres, detalhes em laços ou barras e de infinitas outras maneiras. Um vestido de cetim colado ao corpo é provavelmente uma das peças que mais aproximam o imaginário da intimidade feminina, configurado em uma fronteira mínima entre o corpo oculto e o olhar do outro. Em "A Model” (NIN, 1979), a revelação das coxas da personagem (erógenas até a segunda metade do século XX) ao levantar a saia que sobrepõe o vestido preto de cetim, e de uma pinta (detalhe inesperado), atrai o olhar curioso da narradora-personagem, que descobre ainda que a moça observada não usa calcinha (peça introduzida na moda íntima nas primeiras décadas do século XX).

Outro aspecto interessante desta passagem de "A Model" é a ambiguidade da descrição do vestido: sabemos que ele é coberto por uma outra saia, mas não é mencionada nenhuma blusa. Segundo o historiador de moda James Laver (1989), a última aparição da saia dupla até então ocorreu antes da Primeira Guerra Mundial e foi abandonada com sua eclosão, em prol da praticidade. Esta sobreposição era mais curta que a primeira. De acordo Laver, tecidos nobres como crepe da China e musselina predominavam na belle époque, mas desde a Primeira Guerra e a crise econômica dos Estados Unidos, o mundo é obrigado a se adaptar a uma realidade mais dura e a um vestuário cada vez mais simples e prático, e aos poucos os cortes mais retos, até mesmo com semelhanças à farda militar, e materiais como linho, algodão e casimira são incorporados às vestes femininas, inclusive à noite. Assim como a alegria da belle époque se vai, a das roupas também se apaga.

\footnotetext{
${ }^{3}$ Segundo Daniela Calanca, uma das maiores expressões dos costumes entre os séculos XVI e XVII se dá por meio das roupas íntimas de cor branca (como substitutas da água, substituindo a higiene), que delimitam público e privado. Como exemplo, cita o vestuário luxuoso da época descrito por Pietro Fortini: "O visitante fascinado faz descobertas no momento em que a serva despe a patroa e a prepara para a noite. Descobre uma 'anágua de cetim liso toda adornada com rendas douradas' (...)." (CALANCA, 2011, p.87).
} 
Portanto, a menos que esta narrativa se passe décadas antes do momento em que Anaïs Nin a escreve, um vestido justo de cetim, cujo comprimento não se sabe - cabe dizer que comprimentos acima dos joelhos só começaram a aparecer na década de 1960, quando teve início a busca por uma moda para adolescentes (PROBERT apud Laver, 1989) - sem peça íntima por baixo e escondido por uma saia, pode ser tanto um figurino artístico, quanto uma peça íntima: a anágua, tão fina que é considerada como uma segunda pele desde seu surgimento, na cor branca (CALANCA, 2011). Toda a sedução envolvida neste jogo de mostrar e esconder em uma narrativa erótica possibilita esta última opção. Consciente ou não de que é observada, a atitude da moça atrai o olhar curioso da jovem.

O jogo de mostrar e esconder das roupas simboliza, para além do fetiche erótico, o aprendizado na transição para a vida adulta da personagem que observa a colega da nova profissão. Ao longo da narrativa, outros acontecimentos marcam a passagem da jovem para esta nova fase: no começo, ela conta que passou a adolescência recolhida ao ambiente familiar, e aos dezesseis anos decide conquistar independência pelo trabalho; é assim que chega ao mundo dos artistas e modelos, onde realiza descobertas sobre o amor e a sexualidade. Trata-se da narrativa de uma trajetória em que uma garota inocente ultrapassa os limites do ambiente doméstico para ganhar o mundo. É um movimento de libertação que implica em desvendar os mistérios dos bastidores do meio artístico, da arte erótica e, não menos importante, da vida se expandindo para além do pequeno círculo social na adolescência. A protagonista perde a inocência, mas ganha maturidade através das experiências adquiridas com o tempo, bem como do rompimento da fronteira espacial entre a casa e os salões e ateliês. Logo, a descoberta do corpo do outro (a modelo com vestido preto) contém, implícito, um sentido de descoberta de um outro mundo, o mundo sedutor dos artistas.

\section{Dos corpos nus}

Por outro lado, no conto “The Queen” (NIN, 1979), quando o pintor utiliza formas indeterminadas para desenhar sobre a pele de uma garota de programa, para uma festa temática, e não indica que técnica é utilizada, o primeiro efeito que isto nos causa é a surpresa diante do fato de que o pintor não faz da garota sua modelo, mas a própria tela. O pintor está 
diretamente em contato com a pele nua da moça. O tecido nesta narrativa é um elemento ausente. Passada a surpresa, podemos imaginar se seu traçado e as cores serão mais realistas ou fantásticos, se o acabamento será como uma pintura, uma maquiagem ou uma tatuagem, mas de qualquer modo, o trabalho do pintor é o único traje da moça:

\begin{abstract}
I set about decorating her body with African designs of my own invention. She stood stark naked before me, and at first I stood up and began to paint her shoulders and breasts, and then I crouched to paint the belly and back, then I kneeled and began to paint the lower part of the body and legs... I painted her lovingly, adoringly, like an act of worship.

(..)

When she moved, the bright designs now moved with her, like an oily sea with undercurrents. Her nipples were hard like berries under the touch of the brush. Every curve gave me a delight. (NIN, 1979, p.97)
\end{abstract}

A descrição vaga oferece ainda algumas possibilidades à imaginação, ao mesmo tempo em que é menos palpável na tentativa de uma definição objetiva de como esta pintura se parece. Podemos imaginar como ficou o desenho de acordo com nossos próprios desejos, como gostaríamos que o artista nos pintasse, se estivéssemos no lugar da garota. Outros leitores poderão imaginar como pintariam se ocupassem o lugar do artista, de modo que as sensações se aproximem daquelas descritas pelo narrador. $\mathrm{O}$ gestual do pintor em direção ao corpo/tela é um tanto mais preciso que as formas do desenho, conforme seu investimento na descrição da cena ao narrar esta passagem, com ênfase nos movimentos do artista em contato com o corpo da moça, e não na imagem traçada. A descrição, somada aos sentimentos mencionados pelo narrador, oferece elementos para serem preenchidos pela imaginação.

Já a movimentação do corpo da garota, quando pronto e com a tinta secando, como é descrito pelo narrador-personagem, segundo nosso background pessoal, revela-se para nós como uma paisagem onírica, surrealista. É uma interpretação subjetiva, talvez menos ilusória que uma figura descrita com todos os pormenores, que quase nos faria acreditar no efeito realista, mas que na verdade não passa de uma ilusão referencial (BARTHES, 1972).

Uma descrição que remete a uma pintura e constitui uma ilusão referencial, pela riqueza de detalhes, como Barthes argumenta que Flaubert descrevendo a paisagem de Rouen, surge em outro conto de Anaïs Nin: "The Maja" (1979), que de tempos em tempos retorna à memória e às conversas sobre a produção de contos desta escritora. A descrição de uma mulher espanhola com traços físicos similares à Maja desnuda de Goya, e de sua posição imóvel ao dormir, enquanto é observada e replicada em tela pelo marido, um pintor, transmite aos leitores a sensação de escrutar detalhes de uma nova maja. A beleza da maja de Goya e a 
da personagem de Anaïs Nin causam emoções diferentes, mas ambas andam próximas em nossa imaginação, uma vez que lemos o conto e conhecemos o quadro.

No conto, a personagem feminina veste camisola de seda; no quadro preferido de seu marido, a modelo deita-se sobre a seda. A maja de Goya expõe todo o esplendor de seu corpo, e o mais nobre dos tecidos, que parece acariciar a pele, não representa mais que um agradável repouso. A maja de Anaïs Nin, ao contrário, tem um corpo coberto a ser revelado sob a seda. A trajetória do casal consiste em desnudar esta outra maja dos pudores morais e das roupas. Existe também no conto um jogo erótico de ocultação/revelação, e neste caso o ato de despir é, ademais, a libertação de uma mulher que se priva dos próprios desejos.

\section{Tecendo June no diário}

Se na ficção Anaïs Nin embeleza as narrativas (que frequentemente contêm cenas de violência, sofrimento ou perversidades) com a delicadeza das pinturas e dos tecidos, também em seus diários íntimos com ares romanescos - por vezes ficção e vida real se engendram no estilo da escritora, conforme ela confessa nos diários - a descrição ganha espaço e significação. Um período marcante em que isto ocorre é aquele em que Anaïs Nin e June Miller estão mais próximas, no diário secreto de 1931-1932, publicado com o título de Henry \& June (2014) ${ }^{4}$ :

\footnotetext{
Eu disse:

- Você gosta destas sandálias? - Ela respondeu que sempre gostara de sandálias e as usara até ficar pobre demais para tê-las. Eu disse: - Venha até o meu quarto e experimente o outro par que eu tenho.

Ela as experimentou, sentada em minha cama. Eram pequenas demais para ela. Vi que usava meias de algodão. Mostrei-lhe minha capa preta, que ela achou bonita. Fiz com que a experimentasse, e então vi a beleza de seu corpo, sua exuberância, e isso me arrebatou. (NIN, 2014, p.28)
}

$\mathrm{O}$ aspecto de uma meia de algodão compromete o prazer estético de Anaïs Nin ao contemplar a beleza de June, esposa de Henry Miller. Até a invenção das meias de nylon, o material mais utilizado para a confecção de meias é a seda. O algodão é até hoje uma alternativa utilizada em trajes despojados, enquanto as meias finas são reservadas para ocasiões mais formais. Casada com Hugh Guiller, funcionário em um banco, Anaïs Nin

\footnotetext{
${ }^{4}$ Henry \& June faz parte de uma coleção de diários não ficcionais com revelações muito íntimas, que Anaïs Nin só permitiria que fossem publicados após a morte das personagens envolvidas.
} 
desfruta de uma vida confortável, mesmo não sendo rica, e pode se vestir com elegância. Anaïs Nin não quer deixar a amiga se privar deste privilégio.

Nós nos encontramos no dia seguinte no American Express. Ela veio em seu tailleur
feito sob medida porque eu disse que gostava dele.
Ela havia dito que não queria nada de mim a não ser o perfume que eu usava e meu
lenço cor de vinho. Mas insisti em que ela prometera me deixar comprar sandálias.
Em primeiro lugar eu a fiz ir até o toalete. Abri minha bolsa e tirei um par de meias
finas.
- Vista-as - pedi-lhe. Ela obedeceu. Enquanto isso abri um vidro de perfume. -
Ponha um pouco. - A servente ficou ali, olhando, à espera da gorjeta. Não liguei
para ela. June tinha um furo na manga. (NIN, 2014, p.29)

Sobre o furo na manga, Nin se abstém de comentários, e mais adiante acrescenta que ambas naquele encontro tinham medo mútuo de desagradarem uma à outra. A lacuna entre este furo na manga e a continuação da narrativa, nesta cena, é um punctum na leitura. Para Barthes, em A Câmara Clara, existe uma diferença entre punctum e studium, que coexistem ao olhar para uma fotografia: o studium é o objeto comum do observador, que pode ser compartilhado coletivamente. Aquele elemento familiar a todos que compartilham mais ou menos dos mesmos conhecimentos, facilmente identificado em uma breve mirada. Já o punctum é subjetivo e sobrepuja quem é afetado por ele, é o detalhe impactante, que perturba a paz do observador em uma contemplação mais profunda. Saber do furo na manga por uma única frase, enquanto as meias ocuparam tanto a atenção de Anaïs Nin, é perturbador. Por que ela mencionou este detalhe e não diz mais nada sobre isto? Será este um "detalhe inútill", insignificante? Ou será motivo de desolamento encontrar um defeito na melhor roupa de June, para uma mulher tão sensível às artes e aos costumes quanto Anaïs Nin, e tão atenta aos costumes como uma autêntica francesa? ${ }^{5}$ Se não fosse importante, por que estaria ali, eternizado em um diário íntimo não-ficcional, pelo qual a escritora tinha apego? "June tinha um furo na manga." - esta frase nos atinge como um punctum e frequentemente retornamos a ela em conversas sobre este diário. É possível que, pela presença no diário, este efeito do referente sobre nós seja o mesmo que o do objeto sobre Anaïs Nin.

O furo na manga isoladamente pode não significar muita coisa, mas ele reforça que June e seu marido não têm dinheiro, em um primeiro plano, e também que a personalidade do casal é selvagem quando comparada a Hugh Guiller e Anaïs Nin, naquele momento da

\footnotetext{
${ }^{5}$ Ao final da década de 1920 (um pouco antes de Anaïs Nin conhecer o casal Miller), a moda tornou-se andrógina a ponto de não se distinguir facilmente os sexos senão pela maquiagem das mulheres, porém, considerando os paradigmas de feminilidade vigentes, "a mulher francesa não tem naturalmente a aparência de um menino; ela não se adaptou à nova moda com a facilidade de suas contemporâneas da Inglaterra e dos Estados Unidos.” (LAVER, 1989, p.233). Atribuía-se ao feminino os traços mais curvos e vestuário elaborado, ao masculino eram associadas a fisionomia angular e silhueta longilínea, as vestes eram retas e bem cortadas.
} 
narrativa. Henry Miller é apresentado no diário de Anaïs Nin como a própria figura do escritor boêmio: um bon vivant sensual, sem muito dinheiro, que oculta sua fragilidade. Sua esposa June, ao longo da narrativa, é uma personagem construída tal qual uma autêntica femme fatale: linda, sedutora, atormentada por problemas psicológicos e dotada de potencial (auto)destrutivo. A manifestação maléfica do arquétipo feminino, a "anima negativa" (JUNG apud CHEVALIER \& GHEERBRANT, 1990, p.421) que atrai Henry Miller e o direciona para um abismo.

O amor por June faz com que Anaïs Nin dê um pouco de si mesma à esposa de Henry Miller, por meio de presentes, dinheiro e qualquer movimento em direção a esta mulher de beleza arrebatadora, no ímpeto de satisfazer as necessidades e desejos de June, mas também de colocar um pouco da própria imagem na amiga. Porém June é indisciplinada, haverá sempre algum detalhe danificado, desalinhado ou impróprio, e no fundo é este contraste que atrai Anaïs Nin. June representa o lado da feminilidade que Anaïs Nin desconhece, e que inúmeras vezes é tratado como masculinidade naquele contexto social. Somente na ausência de June, em uma longa viagem, Anaïs Nin encontra em si mesma a força que a atrai em direção à esposa de Miller, em um aprendizado que se dá pelo contato com o escritor e com outros homens que se tornam seus amantes.

\section{A trama que prende a todos: personagens, escritora e leitores}

Voltando à noção de texto como tecido defendida por Barthes, e ainda como uma teia de aranha onde se encontram predador e presa, pensando na desorganização das vestes de June como um sintoma da atmosfera caótica criada por ela, segundo os relatos no diário de Anaïs Nin, não seria a própria June uma aranha tecendo a teia que envolve a escritora? A trajetória de Anaïs Nin entre 1931 e 1932, registrada no diário, mostra uma transformação de esposa recatada de Hugh Guiller a amante intensa, principalmente com Henry Miller. Anaïs Nin projeta uma anima negativa em June, por quem ela mesma se sente atraída, e descreve a si mesma como o contraste de June, a anima benéfica, salvadora do frágil Henry Miller. É como se June tecesse a paixão de Henry, e Anaïs caísse nesta mesma teia.

Em um outro instante, podemos nos perguntar: Será mesmo June a responsável por esta trama caótica que envolve Henry Miller e Anaïs Nin? É importante lembrar que, antes que as duas mulheres se conheçam, Anaïs Nin ouve muito a respeito de June, e vice-versa, 
conforme descobrimos no momento em que se conhecem pessoalmente. A primeira impressão de Anaïs a respeito de June confirma o que Henry diz da esposa: "Eu não pude assimilar seu âmago. Tudo que Henry disse sobre ela era verdadeiro.” (NIN, 2014, p.21). June, por outro lado, revela a Anaïs que as palavras de Henry não conseguem alcançar a escritora: “- Quando Henry a descreveu para mim, disse ela -, ele omitiu as partes mais importantes. Ele não chegou a você absolutamente. - Ela logo soube disso; ela e eu tínhamos nos compreendido, cada detalhe e nuance de cada uma." (NIN, 2014, p.22).

Ademais, June não tem voz própria. Incompreensível e misteriosa, sem o poder da palavra, a atriz torna-se uma personagem criada pela imaginação de outros, o que interfere inclusive na percepção de Anaïs Nin, embora ela mesma consiga identificar que o silêncio de June faz com que nela ecoe a voz alheia.

No final da noite eu era como um homem, terrivelmente apaixonado por seu rosto e por seu corpo, que prometia tanto, e odiava o eu criado nela por outros. Outros sentem por causa dela; e por causa dela, outros escrevem poesia; por causa dela, outros odeiam; outros, como Henry, amam-na apesar deles mesmos. (NIN, 2014, p.21).

Não conhecemos seu posicionamento, pois a atriz é sempre retratada como uma musa, ou como femme fatale, nas narrativas de Henry Miller e Anaïs Nin. Só conhecemos June por outras vozes. Os mais íntimos pensamentos, intenções e sentimentos de June permanecem um mistério. June nos é apresentada segundo outras perspectivas, sempre em posição de alteridade, não como sujeito do discurso. O mutismo de June torna seu âmago tão secreto que em algumas passagens da narrativa ela é representada como alguém superficial. A verdadeira riqueza de June, como personagem, está nos gestos, nos atos simbólicos, como a troca de presentes em demonstração de afeto e de assimilação entre mulheres. Sem ficção, sem biografia e sem diários, June guarda segredos consigo perdidos para sempre, como acontece com muitas outras mulheres, em uma cultura organizada pelo pensamento lógico, na qual os homens detêm o poder da palavra e as mulheres, geralmente, se mantêm em silêncio. (PEGO, 2016). A partir deste pressuposto, podemos concluir que Anaïs Nin, ao escrever e publicar seus diários, repletos de digressões, subverte a ordem social falocêntrica, por isso enfrenta tanta resistência pelo público, ao mesmo tempo em que Henry Miller desfruta de grande popularidade.

A linguagem de June é outra, um enigma para aqueles que dependem do discurso verbal para compreender o mundo, assim como a personagem Ottilie, de Goethe, segundo Walter Benjamin, em As Afinidades Eletivas de Goethe (2009). Esta, por sua vez, escreve 
diários, porém seus pensamentos mais íntimos não ficam registrados naquelas páginas, muito impessoais, que refletem mais os acontecimentos no mundo exterior e as impressões do narrador principal, que o interior da autora dos diários (CARICARI, 2008). Ottilie é uma personagem silente, suas intenções, segundo Benjamin, não são reveladas sequer a si mesma. Procurar extrair os segredos destas mulheres a contragosto, seria um ato violento. "Suponha-se que se fique conhecendo uma pessoa bela e atraente, porém fechada, pois traz em si um segredo. Seria repreensível querer invadir sua esfera íntima.” (BENJAMIN, 2009, p.80).

Quem enreda quem nesta história? June a Henry Miller e Anaïs Nin, ou Henry Miller às duas mulheres? E quanto a Anaïs Nin, qual o seu papel na vida do casal? Não estaria a própria Anaïs Nin, com o poder da palavra, nos direcionando de um lado a outro, nos fazendo crer na protagonista como uma heroína e em June como anti-heroína, como sua antagonista? Mais adiante na narrativa, com uma longa viagem de June, Anaïs Nin e Henry Miller se aproximam, o que faz com que Anaïs Nin tenha receio da volta de June e do sofrimento que ela supostamente causa em Miller com sua presença. Não será esta aura destrutiva que June carrega, na realidade, uma ideia criada por Henry Miller a seu respeito, que convence Anaïs Nin, pois June, permanecendo ausente, não pode demonstrar o contrário? A ausência de June é ao mesmo tempo uma presença fantasmagórica, pois fala-se dela ao longo da obra como alguém que está para chegar e arruinar os amantes, Henry e Anaïs. A narradora-protagonista teme perder Henry e também não ser amada por June, sendo deixada de lado por ambos.

Com o tempo, Anaïs Nin assemelha-se cada vez mais a June, tornando-se um pouco da mulher por quem se encantou no começo da narrativa. Anaïs Nin deseja tornar-se uma mulher fatal. Sente-se frustrada por não conseguir atingir o mesmo patamar de June, como confessa a seu analista. Ainda assim, a mulher delicada e inocente fica no passado, enquanto a nova Anaïs torna-se cada vez mais consciente de sua sensualidade e desejo de amor, de destruição, de vida e intensidade.

Toda esta intensidade faz com que nós, como público leitor, inicialmente sejamos atraídos pela escrita sedutora de Anaïs Nin, depois perturbados pelo andamento da narrativa, mas inevitavelmente impelidos a continuar a leitura do diário. O mesmo acontece com os contos. Descobrimo-nos enredados na teia da obra tecida pela escritora. Somos envolvidos pela atmosfera densa criada entre Henry, June e Anaïs, e também pelas personagens fictícias dos contos, caímos em sua teia, um espaço labiríntico, sem saída. 


\section{REFERÊNCIAS}

BARTHES, Roland. A Câmara Clara: Notas sobre Fotografia. Rio de Janeiro: Nova Fronteira, 1984. Tradução de Júlio Castañon Guimarães.

. Inéditos, Vol. 3: Imagem e Moda. São Paulo: Martins Fontes, 2005. Tradução de Ivone Castilho Benedetti.

. O Efeito de Real. In: BARTHES, Roland (et al). Literatura e Semiologia:

Pesquisas Semiológicas. Petrópolis: Vozes, 1972.

. O Prazer do Texto. São Paulo: Perspectiva, 2010. Tradução de J. Guinsburg.

BENJAMIN, Walter. As Afinidades Eletivas de Goethe. In: Ensaios Reunidos: Escritos sobre Goethe. São Paulo: Duas Cidades, 2009.

CALANCA, Daniela. História Social da Moda. São Paulo: Editora Senac São Paulo, 2011. Tradução de Renato Ambrosio.

CARICARI, Ieda Maria. O Diário de Ottilie: Uma Pérola Dentro do Romance. In: Anais do XI Congresso Internacional da ABRALIC, 2008. Disponível em:

$<$ http://www.abralic.org.br/eventos/cong2008/AnaisOnline/simposios/pdf/079/IEDA_CARIC ARI.pdf $>$. Acesso em 31 de julho de 2019.

CHEVALIER, Jean; GHEERBRANT, Alain. Dicionário de Símbolos. Rio de Janeiro: José Olympio, 1990. Tradução de Vera da Costa e Silva (et. al).

LAVER, James. A Roupa e a Moda: Uma História Concisa. São Paulo: Companhia das Letras, 1989. Tradução: Glória Maria de Mello Carvalho.

NABOKOV, Vladimir. Fala, Memória. Rio de Janeiro: Objetiva, 2014. Tradução de José Rubens Siqueira.

NIN, Anaïs. Henry \& June: Diários Não Expurgados de Anaïs Nin (1931-1932). Porto Alegre: L\&PM, 2014. Tradução de Rosane Pinho.

. Little Birds. New York: Harcourt Brace, 1979.

PEGO, R. D. C. A Imagem do Feminino em Walter Benjamin: Uma Análise da Mulher Através de uma Perspectiva de Gênero. Dissertação (Mestrado em Letras) - Programa de Mestrado em Letras, UFSJ. São João Del-Rei, 2016.

PROBERT, Christina. A Era do Individualismo. In: LAVER, James. A Roupa e a Moda:

Uma História Concisa. São Paulo: Companhia das Letras, 1989. Tradução: Glória Maria de Mello Carvalho.

Recebido em 30/09/2019. Aceito em 04/12/2019. 